\title{
Targeting the Transforming Growth Factor- $\beta$ pathway inhibits human basal-like breast cancer metastasis
}

\author{
Vidya Ganapathy ${ }^{\dagger 1}$, Rongrong Ge ${ }^{\dagger 1}$, Alison Grazioli1, Wen Xie1, Whitney Banach-Petrosky¹, Yibin Kang², \\ Scott Lonning 3 , John McPherson 3 , Jonathan M Yingling ${ }^{4}$, Swati Biswas ${ }^{5}$, Gregory R Mundy 5 and Michael Reiss ${ }^{* 1}$
}

\begin{abstract}
Background: Transforming Growth Factor $\beta$ (TGF- $\beta$ ) plays an important role in tumor invasion and metastasis. We set out to investigate the possible clinical utility of TGF- $\beta$ antagonists in a human metastatic basal-like breast cancer model. We examined the effects of two types of the TGF- $\beta$ pathway antagonists (1D11, a mouse monoclonal pan-TGF$\beta$ neutralizing antibody and LY2109761, a chemical inhibitor of TGF- $\beta$ type I and II receptor kinases) on sublines of basal cell-like MDA-MB-231 human breast carcinoma cells that preferentially metastasize to lungs $(4175 T R, 4173)$ or bones (SCP2TR, SCP25TR, 2860TR, 3847TR).

Results: Both 1D11 and LY2109761 effectively blocked TGF- $\beta$-induced phosphorylation of receptor-associated Smads in all MDA-MB-231 subclones in vitro. Moreover, both antagonists inhibited TGF- $\beta$ stimulated in vitro migration and invasiveness of MDA-MB-231 subclones, indicating that these processes are partly driven by TGF- $\beta$. In addition, both antagonists significantly reduced the metastatic burden to either lungs or bones in vivo, seemingly independently of intrinsic differences between the individual tumor cell clones. Besides inhibiting metastasis in a tumor cell autonomous manner, the TGF- $\beta$ antagonists inhibited angiogenesis associated with lung metastases and osteoclast number and activity associated with lytic bone metastases. In aggregate, these studies support the notion that TGF- $\beta$ plays an important role in both bone-and lung metastases of basal-like breast cancer, and that inhibiting TGF- $\beta$ signaling results in a therapeutic effect independently of the tissue-tropism of the metastatic cells. Targeting the TGF- $\beta$ pathway holds promise as a novel therapeutic approach for metastatic basal-like breast cancer.
\end{abstract}

Conclusions: In aggregate, these studies support the notion that TGF- $\beta$ plays an important role in both bone-and lung metastases of basal-like breast cancer, and that inhibiting TGF- $\beta$ signaling results in a therapeutic effect independently of the tissue-tropism of the metastatic cells. Targeting the TGF- $\beta$ pathway holds promise as a novel therapeutic approach for metastatic basal-like breast cancer.

\section{Background}

In the normal mammary gland, Transforming Growth Factor- $\beta$ (TGF- $\beta$ ) controls tissue homeostasis by inhibiting cell cycle progression, inducing differentiation and apoptosis, and maintaining genomic integrity [1-3]. In addition, TGF- $\beta$ orchestrates the response to tissue injury and mediates repair by inducing epithelial-to-mesenchy-

*Correspondence: michael.reiss@umdnj.edu

1 Division of Medical Oncology, Department of Internal Medicine, UMDNJRobert Wood Johnson Medical School and The Cancer Institute of New Jersey, New Brunswick, NJ, USA

+ Contributed equally

Full list of author information is available at the end of the article mal transition (EMT) and cell migration in a time-and space-limited manner $[4,5]$. Following extracellular activation of TGF- $\beta$, the ligand binds to the type II TGF- $\beta$ receptor (T $\beta R-\mathrm{II})$, which then recruits and activates the type I receptor (T $\beta R-I / A l k-5)[6]$. In general, the activated T $\beta$ R-I/Alk-5 phosphorylates receptor-associated Smad2 and Smad3, which form complexes with Smad4. These activated Smad complexes accumulate in the nucleus where, along with co-activators and cell-specific DNAbinding factors, they regulate gene expression and ultimately cell growth and tissue repair $[7,8]$. More recently it has become apparent that TGF- $\beta$ also activates the recep- 
tor-associated Smads1 and -5 in a T $\beta$ R-I/ALK5-ALK2/3dependent manner, and that this arm of the signaling pathway may be the predominant one driving EMT and cell migration [9-11].

Several correlative studies have suggested that the TGF- $\beta$ signaling pathway plays a critical role in progression of human breast cancer. For example, there appears to be direct correlation between tumor burden and plasma TGF- $\beta$ levels in patients with breast cancer [1215]. In addition, breast cancer tissue appears to express higher levels of TGF- $\beta$ than normal breast tissue [16-19]. Furthermore, a significantly greater fraction of invasive carcinomas express immunodetectable TGF- $\beta$ than in situ carcinomas $[19,20]$.

Besides these correlative studies, genetic manipulation of the intrinsic TGF- $\beta$ signaling pathway in mammary cancer cells has provided direct evidence for its importance in driving the metastatic process (Reviewed in [21]). Thus, McEarchern et al. [22] reported that expressing a dominant negative truncated TGF- $\beta$ type II receptor (TGFBR2) gene in highly metastatic 4T1 murine mammary carcinoma cells significantly restricted their ability to establish distant metastases. Along the same lines, Yin et al. [23] showed that expression of a dominant-negative TGFBR2 receptor mutant in the human MDA-MB-231breast cancer cell line inhibited the extent of experimental bone metastases. Moreover, reversal of the dominant-negative signaling blockade by overexpressing a constitutively active T $\beta R$-I receptor in these breast cancer cells increased production of parathyroid hormone-related protein (PTHrP) by the tumor cells and enhanced their osteolytic bone metastases. In similar studies, Tang et al. showed that introducing a dominantnegative TGFBR2 gene into highly metastatic MCF10Ca1 mammary carcinoma cells resulted in a reduction in experimental pulmonary metastases [24]. More recently, using genetic depletion experiments, several groups have demonstrated that Smad4 [25-27] as well as Smad2 and 3 [28] contribute to the formation of osteolytic bone metastases by MDA-MB-231 cells. Similarly, interference with Smad2/3 signaling strongly suppressed experimental lung metastases of aggressive MCF10Ca breast carcinoma cells [29]. In aggregate, these studies indicate that, even though human breast carcinoma cells are typically refractory to TGF- $\beta$-mediated growth suppression, the remaining intrinsic TGF- $\beta$ signaling contributes to the formation of macrometastases in several different secondary sites, including bone and lungs [23-25]. These studies have generated considerable enthusiasm for exploiting the TGF- $\beta$ pathway as a novel therapeutic target (reviewed in $[21,30])$. However, a number of key questions will need to be answered before embarking on clinical trials of TGF- $\beta$ pathway antagonists in breast cancer.
First, it is necessary to validate the results of genetic depletion experiments using treatment with pharmacological inhibitors of TGF- $\beta$ signaling. Currently, two main strategies for targeting TGF- $\beta$ signaling are in early stages of clinical development [21,31-33]: The first involves trapping of TGF- $\beta$ ligands with soluble T $\beta$ R-II exoreceptor molecules [34] or with isoform-selective antibodies. These include lerdelimumab (selective for TGF- $\beta_{2}$ ) and metelimumab (selective for TGF- $\beta_{1}$ ), as well as the murine 1D11or humanized GC-1008 (Fresolimumab) antibodies that neutralize all three major TGF- $\beta$ isoforms [33]. The second approach involves chemical inhibition of the TGF- $\beta$ receptor kinases [33]. There are a number of key pharmacological and pharmacodynamic differences between these two classes of TGF- $\beta$ antagonists: First, ligand traps are selective for particular ligand(s). For example, 1D11 neutralizes all 3 major active TGF- $\beta$ isoforms (TGF- $\beta 1,-2$, and -3)[35], but does not bind other ligands in the TGF- $\beta$ superfamily, such as activins and BMPs. In contrast, most of the chemical kinase inhibitors inhibit not only Alk-5, -but also the Alk-4 and -7 kinases, thus blocking both TGF- $\beta$ and activin signaling [36-39]. In addition, some of these chemicals, such as LY2109761 (Eli Lilly \& Co.), target both the T $\beta$ R-I and -II kinases [40]. Moreover, the neutralizing antibodies selectively inhibit biologically active TGF- $\beta$ s, while the receptor kinase inhibitors also shut off the basal Smad phosphorylation that is seen in the absence of exogenously added TGF- $\beta$, so called "endogenous" signalling [41]. Finally, tissue and cell penetration of antibodies is often less efficient than of small chemicals, and the target protein needs to be accessible to the antibody to be effectively neutralized. On the other hand, chemicals have more favorable pharmacological properties than the neutralizing antibodies. Because of these differences in target specificity and pharmacological properties, it is difficult to predict which of these compounds will have superior anti-metastatic properties in vivo.

The second major question that needs to be addressed is whether or not metastases to different organ sites are equally dependent on TGF- $\beta$ signaling. In the MDA-MB231 model system, over-expression of a small number of genes is sufficient to selectively confer either bone-tropic or lung-tropic metastatic properties [42,43]. However, the gene expression signature associated with bone metastases is distinctly different from that associated with lung metastases, indicating that a very different type of adaptation is required for MDA-MB-231 to effectively colonize bone marrow or a pulmonary microenvironment [42]. On the other hand, several of the bone- (IL-11, CTGF and CXCR4) and lung metastasis genes (GRO1/ CXCL1, MMP-2, ID1, PTGSG2/COX2) are regulated by TGF- $\beta$ [41]. Therefore, we hypothesize that cell autonomous TGF- $\beta$ signaling plays an important role in pulmo- 
nary metastases as well as in bone metastases. However, not all bone metastases may be equally dependent on autocrine TGF- $\beta$ signaling. Besides rapidly growing bone metastases, some animals developed detectable skeletal metastases following a prolonged period (six months after inoculation) of dormancy (Lu et al. In Preparation) [44]. Cell lines derived from such "post-dormancy" metastases (MDA-231-2860TR and MDA-231-3847TR) retained clear bone-tropism when re-injected into animals, but they lacked expression of previously identified TGF- $\beta$-driven bone metastasis genes, such as CXCR4 or $I L-11$ [44]. Thus, primary lytic bone metastases may be more dependent on TGF- $\beta$ signaling than the ones that develop following dormancy.

In our studies, we used 1D11, a mouse monoclonal pan-TGF- $\beta$ neutralizing antibody [35] and LY2109761, a chemical inhibitor of both T $\beta R-I$ and T $\beta R$-II receptor kinases [40] to determine whether or not these two antagonists have non-overlapping spectra of anti-metastatic activity against breast cancer and whether antimetastatic activity of TGF- $\beta$ pathway inhibitors varies based on tissue tropism using a human basal cell-like breast cancer model.

\section{Results}

Several investigators have demonstrated that genetic inactivation of the TGF- $\beta$ signaling pathway reduces the ability of human basal-like breast cancer cells to metastasize to bones or lungs [23-27,29]. The first question we addressed is whether treatment with pharmacological TGF- $\beta$ antagonists can reproduce the effects of genetically inactivating the tumor cell autonomous TGF- $\beta$ signaling pathway in vitro and in vivo. To this end, we utilized two types of TGF- $\beta$ pathway antagonists, i.e. $1 D 11$, a mouse monoclonal pan-TGF- $\beta$ neutralizing antibody and LY2109761, a chemical inhibitor of TGF- $\beta$ type I and II receptor kinases. We employed experimental metastasis assays in which MDA-MB-231 human breast carcinoma cells were injected either into the left cardiac ventricle to generate osteolytic bone metastases, or into the tailvein to produce pulmonary metastases. To determine whether the efficacy of the TGF- $\beta$ antagonists depended on the type of metastases, we used two types of highly bone-tropic (SCP2-TR and SCP25-TR) or lungtropic (4175-TR and 4173) subclones of MDA-MB-231 that had been isolated by in vivo selection $[25,43,45]$. In addition, during this in vivo selection process, some animals had developed detectable skeletal metastases only after a prolonged period (six months after inoculation) of dormancy [44]. Clonal sublines derived from such "postdormancy" metastases, 2860TR and 3847TR, retained clear bone-tropism when re-inoculated by intracardiac injection. Because their gene expression profiles were quite distinct from the SCP lines, this allowed us to address to what extent the efficacy of TGF- $\beta$ antagonists was dependent on intrinsic properties of tumor cell clones derived from the same parental line.

\section{Distinct morphology of MDA-MB-231 derived subclones in three-dimensional (3D) culture}

Morphologically, the six MDA-MB-231 subclones were indistinguishable from each other when cultured on a plastic substratum. However, when we examined the growth patterns of the various MDA-MB-231 subclones in 3D Matrigel $^{\circ}$ cultures, significant differences were noted (Figure 1). Parental MDA-MB-231 cells have previously been reported to display a stellate growth pattern in $3 \mathrm{D}$ culture [46]. As shown in Figure 1, the two lung-tropic MDA-MB-231 subclones, 4175-TR and 4173, largely retained this distinct stellate morphology, which was associated with pronounced invasion into the surrounding Matrigel'. In contrast, the two bone-tropic subclones, SCP2TR and SCP25TR, displayed a mass-like phenotype, while colonies formed by the two post-dormant subclones, 2860TR and 3847TR, displayed a looser, so-called

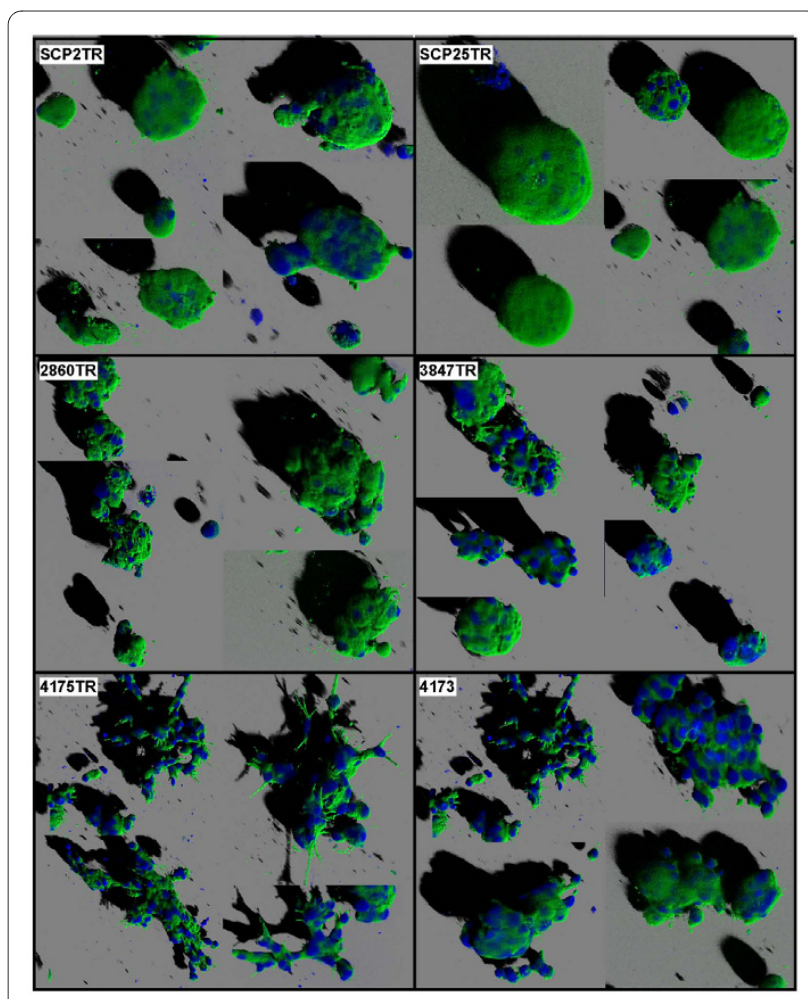

Figure 1 Morphology of MDA-MB-231-derived subclones in 3D organotypic culture. Cells were plated onto a layer of growth factorreduced Matrigel ${ }^{\circ}$ matrix as described in Materials and Methods. Confocal microscopy images of 9 day-old 3D cultures labeled with Alexa488-phalloidin were obtained. Colonies of early (SCP2TR and SCP25TR) and post-dormant (2860TR and 3847TR) bone-tropic subclones displayed a mass-like and grape-like morphology, respectively [46]. In contrast, the two lung-tropic subclones (4175TR and 4173) exhibited a stellate invasive phenotype [46]. 
grape-like, phenotype (Figure 1)[46]. Thus, each of the three clonal subsets displayed a distinct growth pattern in this 3D culture environment, presumably reflecting intrinsic differences in gene expression profiles and their unique metastatic properties in vivo [25,43-45].

\section{Effects of TGF- $\beta$ antagonists on Smad activation in MDA- MB-231 cell clones in vitro}

Since activation of receptor associated Smads (R-Smads) is a required step in TGF- $\beta$ signaling, we examined the effects of treatment with TGF- $\beta$ antagonists on TGF- $\beta$ induced Smad phosphorylation. As shown in Figure 2A, TGF- $\beta$ treatment induced phosphorylation of Smad2 and
-3 in each of the six cell lines. In addition, TGF- $\beta$ clearly induced phosphorylation of Smad- 1 and -5 in the highly metastatic SCP2TR, 4175TR and 4173 clones, to a much lesser extent in the two post dormancy clones (2860TR and 3847TR), and not at all in the moderately metastatic SCP25TR cells (Figure 2A). These findings suggest that the degree of Smad1 and -5 activation may reflect the intrinsic metastatic ability and/or tissue tropism of the different MDA-MB-231 subclones.

Pretreatment of cells with either the T $\beta R$-I and T $\beta R$-II dual kinase inhibitor, LY2109761, or the pan-TGF- $\beta$ neutralizing murine antibody, 1D11, effectively inhibited TGF- $\beta$-induced activation of all R-Smads. Given the dif-

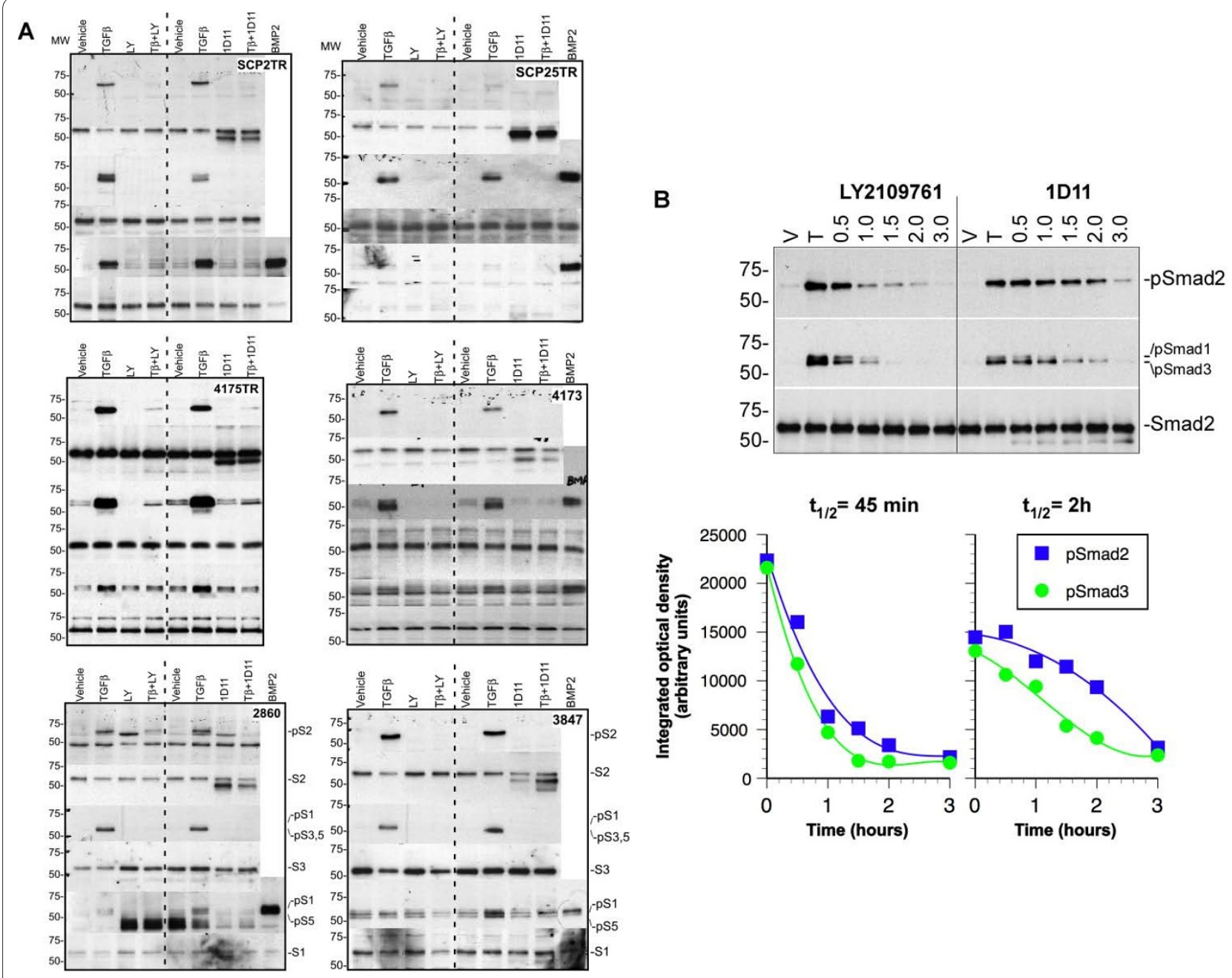

Figure 2 Effects of TGF- $\beta$ antagonists on Smad activation in MDA-MB-231-derived metastatic subclones. A. Cells were starved in serum free DMEM medium overnight and incubated with vehicle or TGF- $\beta$ antagonist for 15 minutes. Subsequently, TGF- $\beta$ (100 pM) was added, and cells were incubated for an additional hour. The levels of phosphorylated Smad-2,-3 and -1/5/8 were determined by Western blotting. Induction of Smad- 2 and -3 phosphorylation by exogenous TGF- $\beta$ was effectively inhibited by either $L Y 2109761(2 \mu \mathrm{M})$ or $1 \mathrm{D} 11(10 \mu \mathrm{g} / \mathrm{ml})$ in all six subclones. TGF- $\beta$ induced Smad 1 and -5 phosphorylation most strongly in the most metastatic bone-tropic (SCP2TR) and lung-tropic (4175TR and 4173) subclones, and to a lesser extent in the 2860TR and 3847TR cells. Activation of these BMP Smads was also inhibited by both antagonists. B. To assess the ability of TGF- $\beta$ antagonists to induce dephosphorylation of R-Smads, bone-tropic SCP2TR cells were treated with TGF- $\beta$ for $1.5 \mathrm{~h}$, followed by treatment with the antagonists for the indicated time-periods. The receptor kinase inhibitor, LY2109761, induced dephosphorylation of activated Smad-2 and -3 more rapidly than the pan- TGF- $\beta$ neutralizing antibody, 1D11. 
ferent pharmacological properties of the two compounds, we also examined their effects on Smad signal termination. Treatment of SCP2TR cells with LY2109761 induced dephosphorylation of Smad2 and -3 much more rapidly $\left(\mathrm{t}_{1 / 2}=45\right.$ minutes) than $1 \mathrm{D} 11\left(\mathrm{t}_{1 / 2}=2 \mathrm{~h}\right.$ )(Figure 2B). Thus, while both LY2109761 and 1D11 were equally capable of blocking TGF- $\beta$-induced signal activation, the kinetics with which they terminated TGF- $\beta$ signaling were quite distinct.

\section{Effects of TGF- $\beta$ antagonists on cell proliferation migration and invasion of MDA-MB-231 clones in vitro}

Treatment with exogenous TGF- $\beta$ failed to significantly affect the growth of MDA-231-4175TR, -4173, SCP25TR, -2860TR and -3847TR cells in vitro (Figure 3A). Moreover, even though TGF- $\beta$ inhibited SCP2TR cell growth by $30 \%$ and this reached statistical significance $(\mathrm{p}=0.029)$, this was far less than in non-neoplastic cells [39]. Most importantly, neither of the two TGF- $\beta$ pathway antagonists significantly stimulated growth of any of the six MDA-MB-231 clones (Figure 3A). Previous studies have suggested that basal cell-like breast cancer invasion and migration might be driven by TGF- $\beta$ [47]. Hence, we determined the effects of each of the antagonists on tumor cell motility and invasion in vitro. As shown in Figures $3 \mathrm{~B}$ and $3 \mathrm{C}$, the MDA-MB-231 subclones differed markedly in terms of intrinsic motility and invasiveness, with SCP2TR and 4175TR being the most motile and invasive. Moreover, exogenous TGF- $\beta$ most strongly stimulated in vitro migration and invasion of these two MDA-MB-231 clones. Interestingly, neither antagonist seemed to have a significant effect on the basal migration rates of any of the subclones (Figure 3B, C). However, treatment with either LY2109761 or 1D11 effectively counteracted TGF- $\beta$-induced migration as well as invasion of SCP2TR and 4175TR cells in vitro. Finally, neither antagonist affected the intrinsic invasion rates of these cell lines in Transwell ${ }^{\circ}$ assays, with the exception of 4173 cells (Figure 3C). Consistent with these findings, treatment of lung-tropic MDA-MB-231 4173 cells in 3-dimensional Matrigel ${ }^{\circ}$ cultures with LY2109761 inhibited spontaneous invasion and caused the cells to revert to a mass-like growth pattern in a dose-dependent manner (Figure 3D). These findings suggested that the invasive properties of MDA-MB-231 4173 colonies in 3D cultures are dependent on autocrine TGF- $\beta$ signaling.

Because SCP2TR and 4175TR cells displayed the highest basal migration and invasion rates, were most strongly stimulated by TGF- $\beta$, and were most susceptible to both TGF- $\beta$ pathway antagonists, these two MDA-MB-231 subclones were selected for in vivo studies.

\section{Effects of TGF- $\beta$ antagonists on bone metastases in vivo}

Several studies have demonstrated that tumor cell autonomous genetic inactivation of the TGF- $\beta$ signaling path- way by knock-down of TGFBR2 or SMAD4 reduced the ability of MDA-MB-231 human basal-like breast cancer cells to metastasize to bone [23,25-27]. Whether these effects could be reproduced by treatment with TGF- $\beta$ antagonists was determined in experimental metastasis assays in which we inoculated athymic nude mice with bone-tropic SCP2TR cells via intracardiac injection. In separate experiments, mice were treated with $5 \mathrm{mg} / \mathrm{kg}$ 1D11 given intraperitoneally (i.p.) three times per week or with $50 \mathrm{mg} / \mathrm{kg}$ LY2109761 twice daily by gavage, beginning 1-3 days following tumor cell inoculation. No drug-associated toxicities were observed and animals maintained their body weight during the entire course of treatment (data not shown). Because the tumor cell lines expressed a luciferase reporter construct, metastases could be monitored in vivo using bioluminescence imaging (BLI) (Figure 4A). Treatment with 1D11 antibody reduced the burden of bone metastases by approximately $70-80 \%$ ( $p=0.001)$ compared to treatment with either vehicle or isotype control antibody (Figure 4A). Similarly, LY2109761 treatment inhibited bone metastases compared to vehicle controls by approximately 55\% ( $\mathrm{p}=$ 0.039) (Figure 4A). Results obtained by BLI were confirmed post mortem using Faxitron analysis (Figure 4B). Perhaps most importantly, treatment with the 1D11 antibody as a single agent was associated with a trend towards prolongation of survival of the test animals (Figure $4 \mathrm{C}$ ).

\section{Effects of TGF- $\beta$ antagonists on pulmonary metastases in vivo}

To address the question whether TGF- $\beta$ signaling plays a similar role in pulmonary metastases as in bone metastases, mice were inoculated with lung-tropic 4175TR cells via tail vein injection (Figure $4 \mathrm{D}$ ). In separate experiments, mice were then treated either with $5 \mathrm{mg} / \mathrm{kg} 1 \mathrm{D} 11$ given intraperitoneally (i.p.) three times per week or with $50 \mathrm{mg} / \mathrm{kg}$ LY2109761 twice daily by gavage, beginning 1-3 days following tumor cell inoculation. Treatment with 1D11 antibody reduced the metastatic burden to lungs by approximately $25-40 \%(\mathrm{p}=0.001)$ compared to treatment with either vehicle or isotype control antibody (Figure 4D). Similarly, LY2109761 treatment reduced the burden of lung metastases compared to vehicle by approximately $40 \%(\mathrm{p}=0.079)$ (Figure $4 \mathrm{C})$. These results indicate that the establishment of pulmonary metastases is also, at least in part, dependent on TGF- $\beta$ signaling. As was the case with bone metastases, the fact that both neutralization of TGF- $\beta$ itself and selective chemical inhibition of the type I and -II TGF- $\beta$ receptor kinases had similar effects in inhibiting pulmonary metastases is indicative of a specific role for TGF- $\beta$ s (as opposed to activins or BMPs) in this process. 

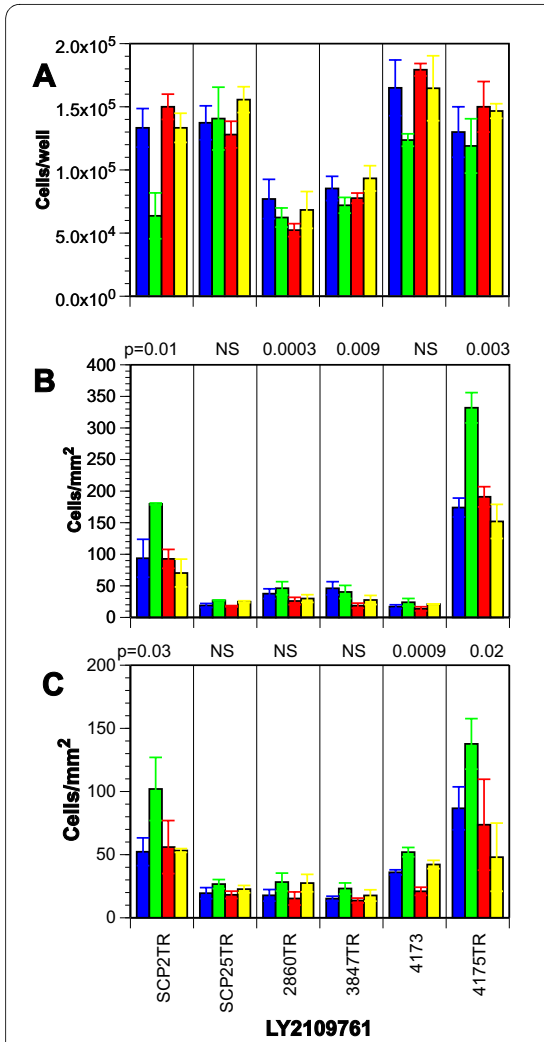
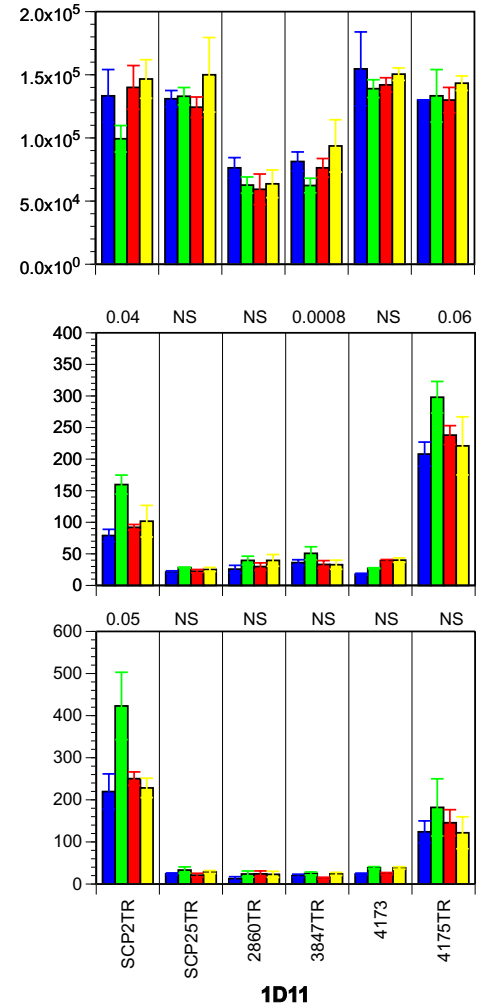

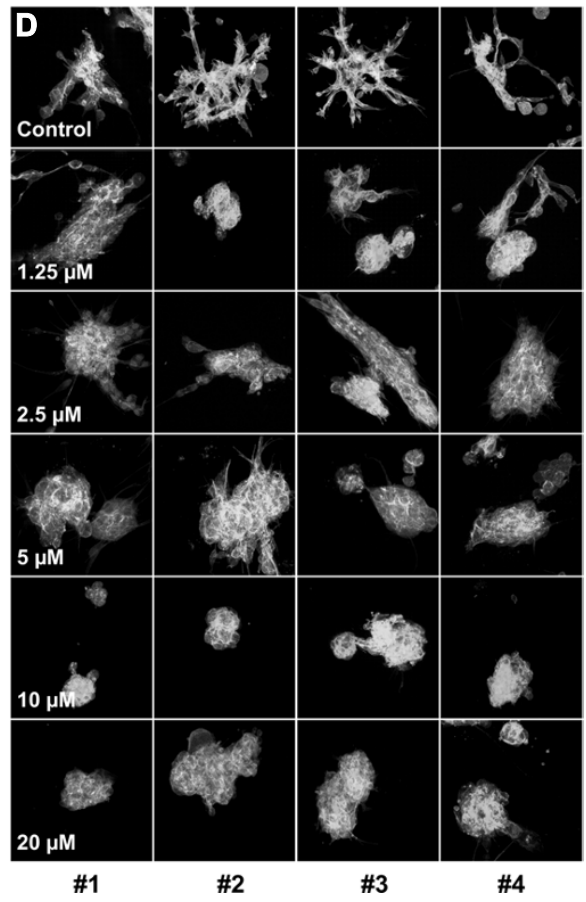

Figure 3 Effects of TGF- $\beta$ and TGF- $\beta$ antagonists on cell growth and cell-motility and -invasion of MDA-MB-231 subclones. A. Cells were plated at $2 \times 104$ well in 24-well plates and incubated in the presence of vehicle (Blue bars), TGF- $\beta$ (100 pM) (Green bars), 1D11 (10 $\mu \mathrm{g} / \mathrm{ml}$ ) or LY2109761 $(2 \mu \mathrm{M})$ (Red bars) or a combination of TGF- $\beta$ and an inhibitor (Yellow bars) for $72 \mathrm{~h}$ and cell numbers determined. Treatment with exogenous TGF- $\beta$ failed to significantly inhibit growth of any of the subclones, with the exception of SCP2TR cells. Neither 1D11 nor LY2109761 stimulated tumor cell growth of any of the MDA-MB-231 subclones. Means \pm SD of at least three independent experiments. Unpaired 2-sided t-test \pm Welch correction was used to compare treatment with or without TGF- $\beta$ antagonist. For cell-motility (B) and -invasion (C) assays, MDA-MB-231 sublines were cultured in uncoated and Matrigel ${ }^{\circ}$-coated PET inserts, respectively. Cells were treated with TGF- $\beta$ (100 pM) and either LY2109761 (2 $\mu M$ ) or 1 D11 (10 $\mu \mathrm{g} / \mathrm{ml}$ ) for $24 \mathrm{~h}$. MDA-MB-231 subclones SCP2TR and 4175TR displayed the greatest motility and invasion, which were further stimulated by exogenous TGF- $\beta$. Moreover, both TGF- $\beta$ pathway antagonists significantly inhibited TGF- $\beta$-induced motility and invasion in these two cell lines. Means \pm SD of at least three independent experiments. Unpaired 2 -sided t-test \pm Welch correction was used to compare treatment with TGF- $\beta$ alone with TGF- $\beta$ plus inhibitor. D. Lung-tropic 4173 cells were plated onto a layer of growth factor-reduced Matrigel ${ }^{\circledR}$ matrix, followed by treatment with either vehicle or varying concentrations of LY2109761 for 9 days. Phase contrast microscopy images of 9 day-old 3D cultures labeled with Alexa-488-phalloidin were obtained. Numbers refer to the four representative colonies from each culture shown. As can be seen, treatment with LY2109761 inhibited invasion into surrounding Matrigel ${ }^{\circ}$ in a dose-dependent manner, resulting in a reversal from a stellate to mass-like phenotype.

\section{Effect of 1D11 on primary versus post-dormant bone metastases in vivo}

MDA-MB-231 bone tropic subclones derived from "postdormancy" bone metastases (2860 TR and 3847 TR) have a distinct gene expression that does not include the previously identified bone metastasis gene signature (Lu et al. In Preparation) [44]. These differences between "primary" and "post dormant" bone-tropic MDA-MB-231 clones allowed us to address to what extent the efficacy of TGF$\beta$ antagonists might differ as a function of intrinsic properties of tumor cell clones derived from the same parental line. Mice were inoculated with post dormant bone tropic 2860 TR cells via intracardiac injection. Treatment with 1D11 antibody reduced the metastatic burden to bones by between $55-80 \%(\mathrm{p}=0.019)$ compared to treatment with vehicle or isotype control antibody (Figure 4E). Thus, TGF- $\beta$ neutralizing antibody 1D11 inhibited bone metastases from 2860 TR cells to a similar degree as those from SCP2TR cells (Figure 4A). In aggregate, the anti-metastatic activity of TGF- $\beta$ targeted agents appears to be relatively independent of the intrinsic differences in gene expression signatures of individual subclones.

\section{Molecular target inhibition by TGF- $\beta$ antagonists in vivo}

To substantiate the inhibition of TGF- $\beta$ signaling by 1 D11 or LY2109761 treatment in vivo, we ascertained the levels of phospho-Smad2 in uninvilved lung tissue and mRNA of several TGF- $\beta$ target genes in kidney tissue of treated animals. Phospho-Smad2 levels were reduced compared to vehicle controls in protein extracts from lungs of ani- 


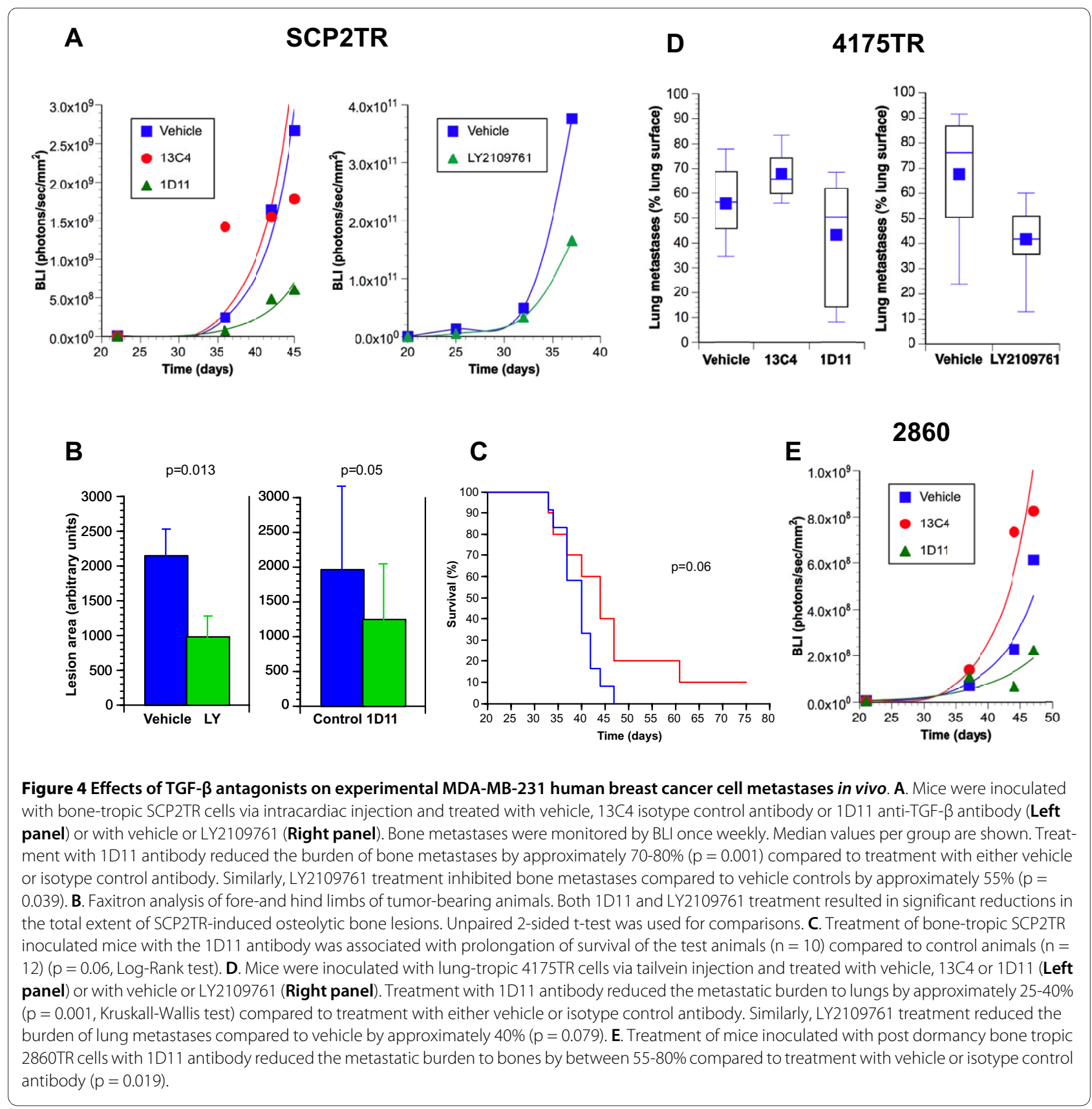

mals treated with either LY2106791 or 1D11 (Figure 5A). As shown in Figure 5B, LY2109761 treatment significantly lowered basal CTGF and PAI-1mRNA expression levels, consistent with blockade of endogenous TGF- $\beta$ signaling in vivo. In contrast, basal TGF- $\beta$ target genes transcript levels were not affected by 1D11 treatment (Figure $5 \mathrm{C}$ ), suggesting that this agent may selectively spare endogenous TGF- $\beta$ signaling [41].

\section{Mechanisms of action of TGF- $\beta$ antagonists in vivo}

In order to assess possible mechanisms of action of the two TGF- $\beta$ antagonists on metastases in vivo, we com- pared the rates of tumor cell proliferation and apoptosis between metastases in the different treatment groups. Consistent with our in vitro results, neither antagonist had a significant effect on tumor cell proliferation (Ki67 staining, Figure 6A) or apoptosis (TUNEL staining, Figure $6 \mathrm{~B}$ ). In contrast, treatment with either $1 \mathrm{D} 11$ or LY2109761 resulted in a significant reduction in microvessel density in lung metastases as determined by CD34 staining (Figure 6C). This suggested that these compounds act, at least in part, by inhibiting tumor angiogenesis. These findings were entirely consistent with our previous findings using a murine model of metastatic 

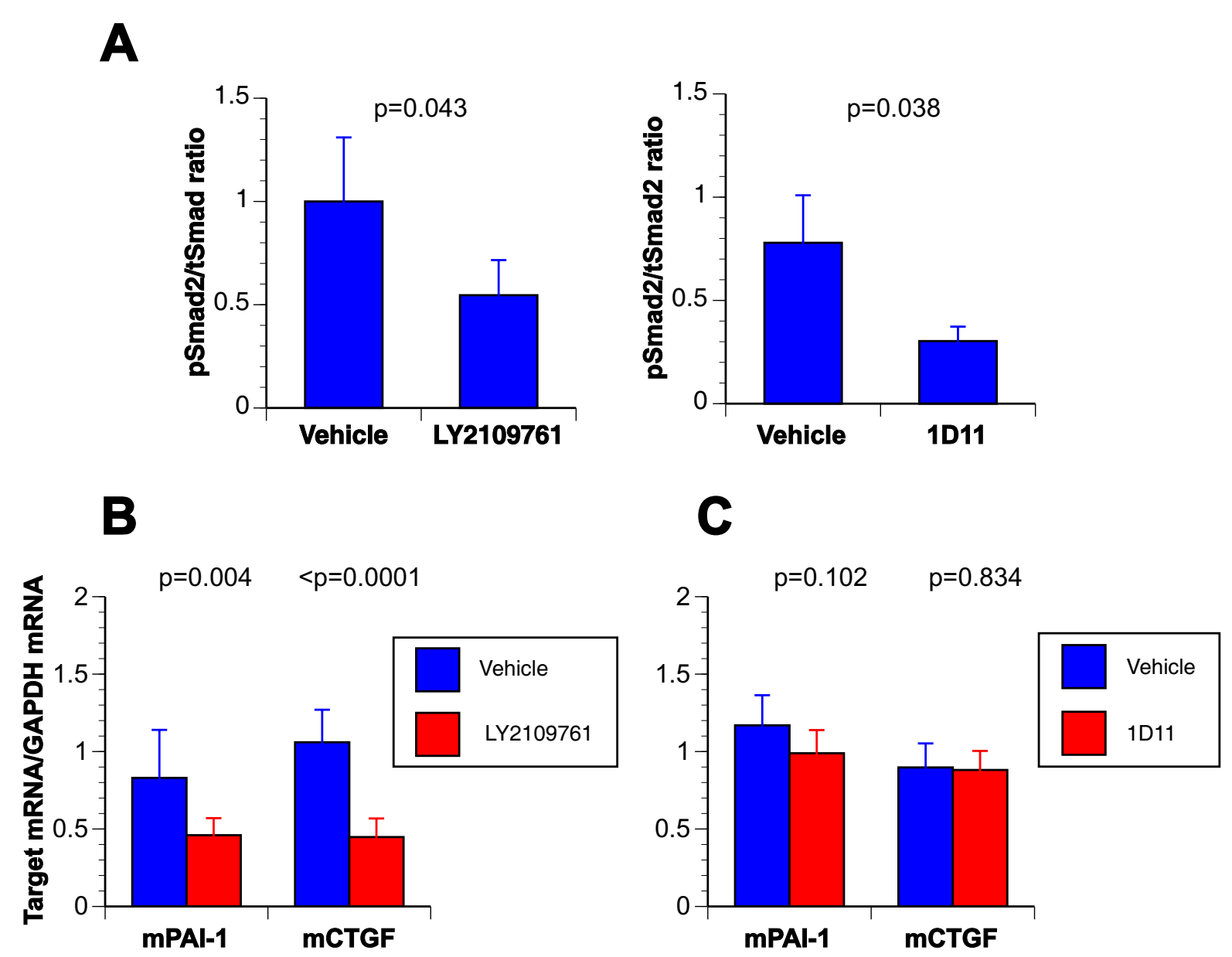

Figure 5 Pharmacodynamic effects of TGF- $\beta$ antagonists in vivo. A. Protein extracts from snap-frozen uninvolved lung tissue of mice treated with vehicle and LY2109761 and of mice treated with controls and 1D11 were prepared and subject to Western blotting using rabbit phosphoSmad2 antibody (1:1000 dilution). Whole cell lysate from SCP2TR was used as a control (Co). Treatment with both antagonists resulted in a reduction of phosphorylated Smad2 levels. Values represent the means and SD of three mice per group. Unpaired 2-sided t-test was used for comparisons. B. RNA was extracted from snap-frozen uninvolved kidneys of mice treated with vehicle or LY2109761 using Trizol reagent (Invitrogen) and purified using RNeasy mini columns (Qiagen) according to the manufacturer's instructions. Transcript levels of CTGF and PAl-1 were assayed using the QuantiTect ${ }^{\text {TM }}$ Probe RT-PCR Kit on a M×4000 Multiplex Quantitative PCR System (Stratagene). Treatment with LY2109761 significantly reduced mRNA levels of both CTGF and PAI-1 relative to GAPDH mRNA. Values represent the means and SD of three mice per group. Unpaired 2-sided t-test was used for comparisons. C. RNA was extracted from snap-frozen lungs of mice treated with vehicle, isotype control antibody or 1D11 and transcript levels determined as described above. No significant reduction in CTGF or PAI-1 mRNA levels could be detected in the 1D11-treated group. Values represent the means and SD of two independent experiments, 3 mice per group. Unpaired 2-sided t-test was used for comparisons.

mammary cancer treated with a different selective TGF- $\beta$ type I receptor kinase inhibitor [48]. As shown in Figure 4, both 1D11 and LY2109761 treatment resulted in significant reductions in osteolytic bone lesions. Consistent with this, histological staining for tartrate resistant acid phosphatase (TRAP) activity, a marker of active osteoclasts, showed that treatment with 1D11 significantly reduced the number of TRAP-positive osteoclasts located at the tumor:bone interface (Figure 6D). In summary, in our xenograft mouse models, the anti-metastatic properties of TGF- $\beta$ signaling antagonists appear to be mediated both by tumor cell autonomous effects and by modulating tumor:host interactions via several different mechanisms, including inhibition of angiogenesis in the case of lung metastases and inhibition of osteoclast activity in the case of bone metastases.

\section{Discussion}

Our study clearly demonstrates that treatment with TGF$\beta$ antagonists inhibits the ability of bone-as well as lungtropic MDA-MB-231 cell lines to establish experimental metastases in vivo. This convincingly demonstrates that TGF- $\beta$ signaling plays an important role in this process, largely independently of the organo-tropism of the tumor 


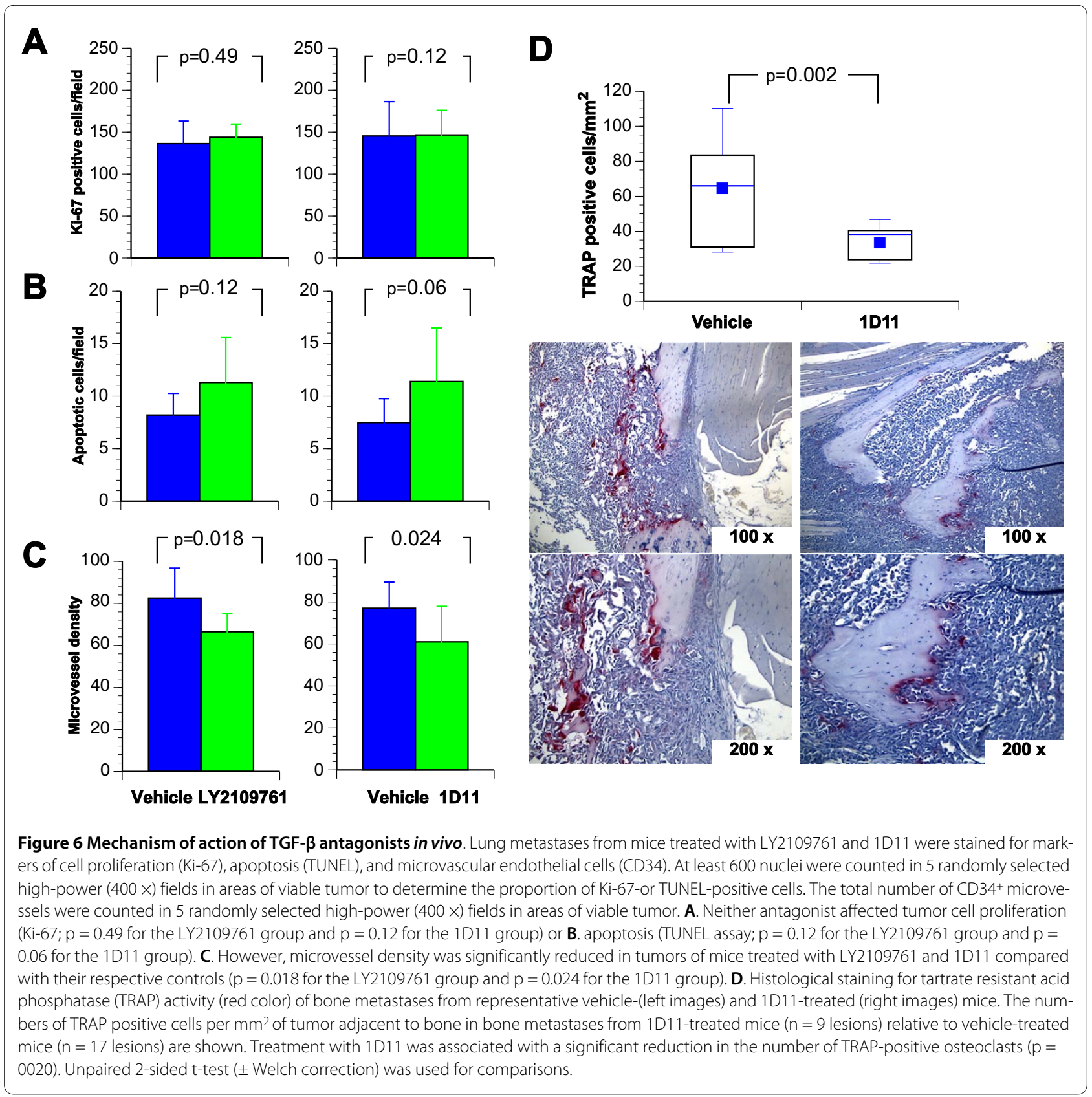

cells (Figure 4). Our results are consistent with several previous studies that have reported anti-metastatic activity of individual TGF- $\beta$ antagonists in in vivo models of human mammary cancer. For example, Arteaga et al. [49] reported that intraperitoneal injections of the murine TGF- $\beta$ neutralizing antibody, 2 G7 (Genentech ${ }^{\circ}$ ), was able to suppress lung metastases of MDA-MB-231 breast cancer cells that had been inoculated intraperitoneally. More recently, using the same experimental metastasis assay we employed, Ehata et al. [50] reported that treatment with a TGF- $\beta$ type I receptor kinase inhibitor, Ki26894, decreased bone metastases and prolonged survival of mice inoculated with highly bone-tropic human MDAMB-231-D breast cancer cells. Similarly, Korpal et al. [27] recently reported that treatment with LY2106791 inhibited early skeletal metastases.

In our hands, both classes of TGF- $\beta$ antagonist significantly reduced the burden of skeletal and pulmonary metastases (Figure 4). Prior to our study, little information was available to determine whether the anti-metastatic efficacy of TGF- $\beta$ antagonists on human breast carcinoma was organ site-specific. Separate reports indicated that the anti-TGF- $\beta$ antibody $1 \mathrm{D} 11$ appeared to inhibit skeletal-or pulmonary metastases of the murine 
4T1 mammary carcinoma cells. Thus, treatment with $1 \mathrm{D} 11$ resulted in a significant reduction in the number of 4T1 lytic bone lesions [51]. Using the same 4T1 cell line, Nam et al. showed that treatment with 1D11 significantly suppressed both the number and size of tumor metastases to the lungs [52-54]. Although one has to be cautious about direct comparisons across studies, the therapeutic effects of TGF- $\beta$ neutralizing antibodies against 4T1derived skeletal or pulmonary metastases appeared to be of a similar order of magnitude.

Although our results are consistent with previous reports of anti-metastatic activity of individual TGF- $\beta$ antagonists in in vivo breast cancer models, none of the previous studies have conducted a comparison between two different pharmacological strategies to inhibit TGF- $\beta$ signaling. Thus, our second most important finding is that both neutralization of active TGF- $\beta$ s using the 1D11 antibody and inhibition of TGF- $\beta$ receptor kinases using the dual receptor kinase inhibitor, LY2109761, resulted in quantitatively remarkably similar degrees of inhibition of experimental metastases to both bone and lungs. Besides inhibiting the TGF- $\beta$ type I (and -II) receptor kinases, LY2109761 also inhibits the activin receptor kinases, Alk4 and Alk-7. This is a property shared by all known other members of this class of compounds, raising the concern that their biological activity may be mediated by either TGF- $\beta$ s or activins. On the other hand, 1D11 is specific for bioactive TGF- $\beta$ s and does not neutralize any of the other TGF- $\beta$ superfamily members, including activin or BMPs. Thus, the qualitatively and quantitatively similar anti-metastatic effects we observed using both compounds in both experimental metastasis assays strongly support a specific role for TGF- $\beta$ in this process, and essentially exclude the possibility that the effects we observed were due to interference with either activin-or BMP signaling.

In vitro, treatment with exogenous TGF- $\beta$ induced Smad2/3 phosphorylation in all six MDA-MB-231 subclones and both TGF- $\beta$ antagonists were capable of blocking Smad2/3 signal activation (Figure 2). In addition, both compounds effectively cause Smad2/3 signal termination, albeit that LY2109761 induced dephosphorylation of Smad2 and -3 more rapidly than 1D11. Consistent with these in vitro findings, in vivo, phosphoSmad2 levels were reduced in lungs of animals treated with either compound compared to vehicle treated controls (Figure 5). Moreover, LY2109761 treatment partly inhibited mRNA expression of TGF- $\beta$ target genes, consistent with blockade of endogenous TGF- $\beta$ signaling in vivo. These results are consistent with our previous findings using the TGF- $\beta$ type I receptor inhibitor, SD-208, in the syngeneic $4 \mathrm{~T} 1$ mammary cancer model [48]. In contrast, 1D11 treatment was not associated with a significant reduction in target gene transcript levels by in vivo, suggesting that this agent only neutralizes activated ligand and selectively spares endogenous TGF- $\beta$ signaling.

We and others have recently reported that, besides Smad2 and -3, TGF- $\beta$ also activates the BMP Smads, Smad1 and -5 , in normal and malignant mammary and epidermal epithelial cells [9-11,55,56]. Moreover, the degree to which exogenous TGF- $\beta$ induced Smad1/5 phosphorylation in the different subclones appears to reflect their metastatic ability in vivo (Figure 2). Thus, the activation state of BMP Smads should be explored as a predictive biomarker of response to TGF- $\beta$ antagonists in a clinical setting.

A major unresolved question is whether and under which conditions the predominant role TGF- $\beta$ plays is mediated by its tumor cell autonomous effects, or via its actions on the host microenvironment. We approached this question by comparing two types of bone-tropic MDA-MB-231 subclones. Following intracardiac inoculation with MDA-MB-231 cells, some animals developed skeletal metastases following a prolonged period of dormancy (Lu et al., In Preparation). Cell lines derived from these "post-dormancy" metastases retain clear bone-tropism when re-injected into secondary animals, but display a gene expression profile that is quite distinct from that found in the "primary" bone metastases (Lu et al. In Preparation) [44]. However, when we treated mice that had been inoculated with post-dormancy bone tropic 2860 TR cells with the 1D11 TGF- $\beta$ neutralizing antibody, the development of skeletal metastases was inhibited to a similar extent as in SCP2-TR inoculated mice (Figure 4). Thus, 1D11 appeared to be anti-metastatic independently of the intrinsic gene expression profile of individual bone tropic tumor cell clones derived from the same parental cell line. These results suggest that, at least in this MDA-MB-231 in vivo model, TGF- $\beta$ 's pro-metastatic activity may be mediated predominantly by its actions on host cells within the bone microenvironment, rather than by autocrine effects on the tumor cells themselves. Consistent with this idea, neither LY2109761 or 1D11 treatment inhibited tumor cell proliferation or induced tumor cell apoptosis, in vivo (Figure 6).

In response to activated TGF- $\beta$ released from bone matrix, MDA-MB-231 cells secrete a number of signaling molecules, including PTHrP and RANK-L, that stimulate osteoclast activity [23]. Osteoclast-mediated bone breakdown is thought to release TGF- $\beta$, thereby resulting in a "vicious cycle" that leads to progressive bone destruction [57]. Thus, we predicted that treatment with TGF- $\beta$ antagonists would decrease osteoclast activation in the context of MDA-MB-231 bone metastases. In fact, 1D11 treatment resulted in a significant reduction in the number of active osteoclasts at the tumor:bone interface (Figure 6). Similarly, Futakuchi et al. [57] recently reported 
that treatment with 1D11 inhibited osteoclast activation and osteolytic bone destruction by $4 \mathrm{~T} 1$ mammary carcinoma cells in vivo. In this study, identical effects were obtained using a chemical TGF- $\beta$ type I receptor kinase inhibitor [57]. Consistent with these findings, Mohammad et al. [58] recently reported that treatment with the TGF- $\beta$ type I receptor kinase inhibitor, SD-208, increased osteoblast differentiation and bone formation, while reducing osteoclast differentiation and bone resorption. In aggregate, these studies have clearly demonstrated that pharmacological blockade of TGF- $\beta$ signaling shifts the balance from bone breakdown to bone (re)generation, thereby inhibiting tumor-associated osteolysis.

In the lung metastasis model, treatment with TGF- $\beta$ pathway antagonists inhibited tumor angiogenesis, as reflected by a decrease in CD34-positive microvessel density. These findings are consistent with our own earlier studies of the effects of the T $\beta R-I$ kinase inhibitor, SD-208, against 4T1 lung metastases [48]. Similarly, Nam et al. [54] reported that treatment with 1D11 was associated with a statistically significant decrease in microvessel density in 4T1 murine mammary tumors. Consistent with these findings, treatment of $4 \mathrm{~T} 1$ tumor bearing mice with the $2 \mathrm{G} 7$ anti-TGF- $\beta$ neutralizing antibody significantly reduced circulating VEGF levels [59](Genentech, US Patent Application 2005/0276802 A1). Thus, at least in lung metastases, TGF- $\beta$ pathway antagonists have been consistently found to exert modest anti-angiogenic effects against basal-like mammary cancer in vivo.

Even though both TGF- $\beta$ antagonists clearly had a demonstrable anti-metastatic effect in the MDA-MB-231 human breast cancer models, neither of the two agents completely abolished skeletal or pulmonary metastases. In part, this may be due to the fact that we had to use immunodeficient mice as hosts for human tumor cells because TGF- $\beta$ pathway antagonists have been shown to de-repress anti-tumor immunity in mouse models of mammary cancer $[48,49,52-54]$. For example, we ourselves demonstrated that treatment with the TGF- $\beta$ type I receptor kinase inhibitor, SD-208, inhibited spontaneous pulmonary metastases of R3T mammary carcinoma cells much more strongly in syngeneic than in nude mice [48]. Published studies have demonstrated that tumor-associated TGF- $\beta$ not only suppresses NK cell activity and Tcell mediated anti-tumor responses, but also actively subverts the $\mathrm{CD}^{+}{ }^{+}$arm of the immune system into directly promoting tumor growth by an IL-17-dependent mechanism $[48,49,52-54]$. As we utilized athymic nude mice as hosts, we cannot ascribe the observed anti-metastatic effects of TGF- $\beta$ antagonists to stimulation of T-celldependent processes. Moreover, even though Arteaga et al. were able to detect an effect on NK cells, even in the MDA-MB-231 model [49], we were unable to detect an increase in NK cell infiltration into metastases of 1D11 or
LY2109761 treated animals in the current study (data not shown). Thus, we predict that treatment with TGF- $\beta$ antagonists will have significantly greater anti-metastatic impact when applied in the context of a syngeneic host, in which they will act by a cooperative mechanism that involves several different cellular compartments, including the $\mathrm{CD}^{+} \mathrm{T}$ cells, $\mathrm{NK}$ cells, the microvasculature, osteoclasts and the tumor cells themselves [54].

Finally, we should note that all of the pre-clinical studies of TGF- $\beta$ pathway antagonists in mammary cancer reported to date, have employed cell lines derived from basal-like tumors. Thus, these studies preclude any conclusions regarding the possible anti-metastatic activity these compounds may or may not have in the context of estrogen-dependent or HER2-mediated breast cancers. In fact, a wealth of experimental and clinical evidence suggests that, as long as breast cancers remain dependent on estrogens, TGF- $\beta$ protects against rather than promotes tumor progression [21]. Thus, one has to be cautious in extrapolating the results from the current and other preclinical studies of TGF- $\beta$ pathway antagonists to breast cancers other than those of the basal-like subtype.

\section{Conclusions}

In summary, pre-clinical studies in several different syngeneic as well as allogeneic mammary cancer models have provided convincing evidence that targeting the TGF- $\beta$ pathway using either a TGF- $\beta$ neutralizing antibody or receptor kinase inhibitors can inhibit both early lung and bone metastases of basal-like breast cancer. Our findings are consistent with the concept that TGF- $\beta$ signaling plays several different roles in the complex interplay between tumor and host cells that constitute the premetastatic niche. The signaling pathway appears to be fundamentally altered in tumor cells in such a way that the tumor cells interpret incoming signals as pro-invasive, while they are no longer growth inhibited. This results in the secretion of TGF- $\beta$-induced metastasiseffector proteins, which exert pro-metastatic actions on the host microenvironment. Our studies provide substantive support for clinical trials of TGF- $\beta$ antagonists for patients with basal-like breast cancer.

\section{Methods \\ Reagents}

Human recombinant TGF- $\beta 1(1 \mu \mathrm{g} / \mathrm{mL}$; Austral Biologicals, San Ramon, CA) was dissolved in $4 \mathrm{mmol} / \mathrm{L} \mathrm{HCl}$ and $1 \mathrm{mg} / \mathrm{mL}$ bovine serum albumin (Sigma, St. Louis, MO). $1 \mathrm{D}-11$ and the isotype-matched murine IgG1 monoclonal control antibody, 13C4, directed against Shigella toxin, (Genzyme, Framingham, MA) was diluted in formulation buffer composed of $0.1 \mathrm{M}$ glycine, $70 \mathrm{mM}$ $\mathrm{Na}_{2} \mathrm{HPO}_{4}, 0.0011 \%$ Tween 20 for both in vitro and in vivo studies. A 10 mM stock solution of LY2109761 (Eli Lilly 
and Co., Indianapolis, IN) in DMSO (Sigma, St. Louis, MO) was prepared for in vitro studies. For in vivo studies, LY2109761 was suspended in a formulation composed of $1 \%$ sodium carboxy methylcellulose (NaCMC), $0.5 \%$ sodium lauryl sulfate (SLS), $0.05 \%$ antifoam and $0.085 \%$ polyvinylpyrrolidone (PVP).

\section{Cell culture}

MDA-231-SCP2TR, MDA-231-SCP25TR, MDA-2312860TR and MDA-231-3847TR are clonal sublines of MDA-MB-231 (ATCC) human breast carcinoma cells with distinct organ-specific metastatic behavior that were generated by one of us (YK) [25,42]. MDA-231-4175TR and MDA-231-4173 were obtained from Dr. Joan Massagué (Sloan Kettering Institute, New York, NY). All MDA-MB-231 sublines were maintained in DMEM (Invitrogen, Carlsbad, CA) supplemented with 10\% FBS (Sigma, St Louis, MO).

\section{Cell proliferation assays}

Cells were plated at $2 \times 10^{4}$ cells/well in 24 well cluster dishes (Corning Inc. Corning, NY), overnight. Cells were treated initially with $10 \mu \mathrm{g} / \mathrm{ml} 1 \mathrm{D} 11$ or $2 \mu \mathrm{M}$ LY2109761 for 15 minutes followed by addition of 100 pM TGF- $\beta 1$ and incubated at $37^{\circ} \mathrm{C}$ for $72 \mathrm{~h}$. Subsequently, cells were washed with $1 \mathrm{ml}$ ice-cold PBS, and detached with $0.2 \mathrm{ml}$ trypsin-EDTA (Invitrogen, Carlsbad, CA). Trypsin was neutralized by adding $0.8 \mathrm{ml}$ of the culture medium containing 10\% FBS, and the cells counted using a Vi-cell particle Counter (Beckman Inc, Miami, FL).

\section{Western blot analysis}

To determine the effects of TGF- $\beta$ antagonists on TGF- $\beta$ induced R-Smad phosphorylation, MDA-MB-231 sublines were incubated in serum free medium overnight and treated with $2 \mu \mathrm{M}$ LY2109761 or $10 \mu \mathrm{g} / \mathrm{ml} 1 \mathrm{D} 11$ for 15 minutes, followed by the addition of 100 pM TGF- $\beta 1$ for one hour. The vehicle control, DMSO, was used at a final concentration of $0.01 \%$, which was not toxic to cells. For dephosphorylation assays, cells were initially treated with 100 pM TGF- $\beta$ for 1.5 hour followed by three washes with serum free medium. Subsequently, cells were treated with either $2 \mu \mathrm{M}$ LY2109761 or $10 \mu \mathrm{g} / \mathrm{ml} 1 \mathrm{D} 11$ for $0.5,1,1.5,2$ and 3 hours. Cells were then lysed in situ using buffer composed of $150 \mathrm{mM} \mathrm{NaCl}, 10 \mathrm{mM}$ Tris$\mathrm{HCl}$ (pH 8.0), 1 mM EGTA, 1\% (v/v) Triton-X-100 in the presence of protease inhibitors and phosphatase inhibitors (Complete Mini Protease Inhibitor Cocktail Tablets with EDTA, and PhosSTOP, Roche Diagnostics Corporation, Indianapolis, IN), for $30 \mathrm{~min}$ at $4^{\circ} \mathrm{C}$. Cell lysates were collected and clarified by centrifugation at 12,000 rpm for 10 minutes at $4^{\circ} \mathrm{C}$. The clarified lysates were then subjected to SDS-PAGE and transferred to nitrocellulose membranes using a Panther ${ }^{\text {ra }}$ Semidry Electroblotter
(Owl Separation Systems, Portsmouth, NH). Activated Smad2 (pSmad2), Smad3 (pSmad3) and Smad1/5/8 (pSmad1/5/8), were detected using monoclonal rabbit anti-human pSmad2, polyclonal rabbit anti-human pSmad3 and polyclonal rabbit anti-human pSmad1/5/8 antibodies (Cell Signaling, Danvers, MA) at 1:1000 dilutions. Total Smad2, Smad3 and Smad1 were detected using mouse monoclonal anti-human Smad2 (Cell Signaling, Danvers, MA), rabbit monoclonal anti-human Smad3 (Zymed Laboratories, South San Francisco, CA) and rabbit monoclonal anti-human Smad1 (Cell Signaling, Danvers, MA) antibodies at 1:400, 1:500, 1:1000 dilutions, respectively. Blots were developed using a 1:2000 dilution of horseradish peroxidase-tagged goat anti-rabbit (Calbiochem, San Diego, CA) or anti-mouse (Vector Labs, Burlingame, CA) IgG antibody and the bands visualized using $\mathrm{ECL}^{\mathrm{mi}}$ (Amersham, Piscataway, NJ) reagent. Blots were scanned using a Canoscan Lide500F photo scanner and integrated optical densities of individual bands on scanned images were determined using Image J v.1.41 software (NIH).

\section{In vitro cell motility and invasion assays}

Uncoated polyethylene terephthalate (PET) track etched membrane (24-well insert, pore size $8 \mu \mathrm{m}$; BD Biosciences, Franklin Lakes, NJ) inserts were equilibrated by adding $0.5 \mathrm{ml}$ cell culture medium without FBS to the upper and lower chambers followed by incubation at $37^{\circ} \mathrm{C}$ for $2 \mathrm{~h}$. The medium used for equilibration was aspirated gently and upper chambers were seeded with $10^{5}$ cells in $0.5 \mathrm{ml}$ of cell culture medium. TGF- $\beta$ (100 pM) and/or 1D11 $(10 \mu \mathrm{g} / \mathrm{ml})$ or LY2109761 $(2 \mu \mathrm{M})$ were added to both the upper and lower chambers. Following a 24hour incubation at $37^{\circ} \mathrm{C}$, cells in suspension were removed by washing twice with $\mathrm{PBS}$ and cells adherent to the top of the inserts removed by scraping the upper surface of the membrane with cotton tip applicators. The cells that had migrated to the underside of the inserts were fixed and stained using the Diff-Quick (Dade Behring, Newark, DE) staining kit as per manufacturer's instructions. Cells in ten random squares of $0.1 \mathrm{~mm}^{2}$ in each well were counted at $200 \times$ magnification, using 3 duplicate wells per assay condition, and expressed as number of cells per $\mathrm{mm}^{2}$. Invasion assays were carried out in an identical manner using Matrigel $^{\circ}$ coated PET inserts (BD Biosciences, Franklin Lakes, NJ).

\section{Organotypic three-dimensional (3D) cultures}

3D cultures were carried out as described by Debnath et al [60]. Briefly, 5000 cells were plated on top of solidified Growth Factor Reduced Matrigel ${ }^{\circ}$ (BD Biosciences, Franklin Lakes, NJ) in each well of an 8 well chamber slide. Cells were fed every other day with cell culture medium containing $2 \%(\mathrm{v} / \mathrm{v})$ Matrigel $^{\circ}$. Cells were washed 
with PBS on day 9 and fixed with buffered formalin for 10 minutes. For dose-response studies, cells were treated with vehicle (DMSO $0.28 \%$ ), or with varying concentrations of LY2109761. All dilutions were made in cell culture medium supplemented with $10 \%$ (v/v) FBS and $2 \%$ (v/v) Matrigel ${ }^{\circ}$. Cells were fed every other day with vehicle and LY2109761. On day 9, cells were fixed and permeabilized using Triton-X 100 for 5 min, washed with PBS and incubated in the dark with Alexa Fluor 488 Phalloidin (1:40 dilution in PBS with 1\% BSA, Invitrogen, Carlsbad, CA). The nuclei were stained using Topro-3 (1:150 dilution, Invitrogen) for 15 minutes. Stained slides were mounted with Prolong Antifade Reagent (Invitrogen, Carlsbad, CA) and photographed using a Zeiss epifluorescence microscope equipped with a MTI CCD camera and Nikon C1 confocal microscope. Volocity software (Improvision, Waltham, MA) or Huygens Professional software (Scientific Volume Imaging, Hilversum, Netherlands) renderer modules were used to generate perspective renderings of each image stack.

\section{Experimental metastasis assays}

MDA-231-4175TR tumor cells were injected into the tail vein $\left(2 \times 10^{5}\right.$ cells $)$ and MDA-231-SCP2TR $\left(1 \times 10^{5}\right.$ cells $)$ and MDA-231-2860TR $\left(5 \times 10^{5}\right.$ cells $)$ were injected into the left cardiac ventricle of viral antibody-free 4- to 5week-old female athymic nude mice (Harlan Laboratory, Indianapolis, IN) to give rise to experimental lung and bone metastases, respectively $[42,43]$. Starting the following day, mice were treated with $5 \mathrm{mg} / \mathrm{kg} 1 \mathrm{D} 11$ anti-TGF- $\beta$ antibody, 13C4 control antibody or buffer by intraperitoneal injection 3 times/week until tumor growth required sacrifice [61]. Alternatively, mice were treated with 50 $\mathrm{mg} / \mathrm{kg}$ LY2109761 or $0.2 \mathrm{~mL}$ of vehicle by gavage twice a day, beginning on the second or third day following tumor cell inoculation, until the animals were sacrificed [62]. Body weight and bioluminescence were monitored weekly. For bioluminescence imaging (BLI), anesthetized mice were injected with $100 \mathrm{mg} / \mathrm{kg}$ d-Luciferin (Xenogen, Alameda, CA) in PBS intraperitoneally, and images were acquired using a Kodak 2000 MM Multimodal Imaging Station with cooled CCD camera (Carestream Molecular Imaging, New Haven, CT). Acquisition time was adjusted to avoid saturation of the signal. Analysis of the images was performed using Kodak Molecular Imaging Software Version 4.5 by first converting the signal to photon flux (measured in photons $/ \mathrm{sec} / \mathrm{mm}^{2}$ ), identifying regions of interest with a pixel density above background using the auto ROI feature of the software, and recording the sum of the background-subtracted pixel values within each ROI. Results are reported as bioluminescence per treatment group corrected for the number of mice per group. Post mortem, radiographic images from dissected forelimbs and hind limbs of the tumor bearing animals were taken using X-rays at $35 \mathrm{kVp}$ for 8 seconds using a Faxitron LX-60 X-ray cabinet (Faxitron X-Ray, LLC, Lincolnshire, IL). The images were then used to quantify lesion areas using MetaMorph 7.5 image analysis software (Molecular Devices, Sunnyvale, CA). Lung wet weight at the time of sacrifice was determined and expressed as a fraction of body weight. In addition, anterior and posterior photographic images of lungs were obtained from each animal post mortem and the fraction of lung surface occupied by metastases determined using NIH Image J (version 1.41) image analysis software. Besides lungs and bones, liver, kidneys, adrenal glands, and major lymph node groups were visually inspected for the presence of tumor metastases. Organs were fixed in formalin for $24 \mathrm{~h}$ and then placed in $70 \%$ ethanol until further histological assays were performed. In addition, uninvolved kidneys and lungs were snap frozen in liquid nitrogen for pharmacodynamic studies using RT-PCR and Western blot analysis.

\section{Cell proliferation-, apoptosis and angiogenesis}

Tissue sections were deparaffinized, rehydrated, and stained with hematoxylin and eosin $(\mathrm{H} \& \mathrm{E})$, rat antimouse monoclonal CD34 IgG2a (1:100; CL8927AP; Cedarlane, Hornby, Canada), or rabbit polyclonal anti-Ki67 (1:100; ab833-500; Novus Biologicals, Littleton, CO). Control slides were stained using appropriate isotope control antibodies. Biotinylated secondary antibodies (1:150; Zymed, San Francisco, CA) were used for detection. The total number of CD34-positive microvessels were counted in 5 randomly selected high-power $(400 \times)$ fields in areas of viable tumor. To assess the percentage of proliferating cells, the proportion of Ki-67-positive nuclei was determined. At least 600 nuclei were counted in 5 randomly selected high-power $(400 \times)$ fields in areas of viable tumor. Apoptotic cells were identified by terminal deoxynucleotidyl transferase-mediated nick-end labeling (TUNEL) assay using the In Situ Cell Death Detection Kit (Roche Molecular Biochemicals, Indianapolis, IN). To assess the degree of apoptosis, TUNEL-positive cells were counted in the tumor in 5 randomly selected highpower $(400 \times)$ fields in areas of viable tumor.

\section{Histological staining for tartrate resistant acid phosphatase (TRAP)}

For TRAP staining, bones were fixed in $10 \%(\mathrm{v} / \mathrm{v})$ formalin followed by decalcification in $0.5 \mathrm{M}$ EDTA. Slides were incubated with pre-warmed $10 \%(\mathrm{v} / \mathrm{v})$ naphtholether (0.044 M 7-bromo-3-hydroxy-2-naphthoic-o-anisidide phosphate in ethylene glycol monoethyl ether) in basic incubation medium ( $0.112 \mathrm{M}$ sodium acetate, 0.05 $\mathrm{M}$ disodium tartrate dihydrate) at $37^{\circ} \mathrm{C}$ for 30 minutes. Slides were then transferred directly into $2 \%(\mathrm{v} / \mathrm{v})$ color reaction medium (1:1 mixture of $0.058 \mathrm{M} \mathrm{NaNO}_{2}$ and 
$0.154 \mathrm{M}$ pararosaniline chloride in $2 \mathrm{M} \mathrm{HCl}$ in basic incubation medium), and incubated for 5 to 30 minutes at room temperature. Once optimal staining was achieved, slides were rinse in deionized water and counterstained using Harris's acid hematoxylin. The number of TRAP positive cells per $\mathrm{mm}$ of tumor adjacent to bone were used as a measure of osteoclast activity [27].

\section{Real-time quantitative RT-PCR}

Transcript levels of individual genes were assayed in frozen tissue specimens by quantitative real time (qRT)PCR, using the QuantiTect ${ }^{\text {th }}$ Probe RT-PCR Kit (QIAGEN, Valencia, CA). For the PCR, $50 \mu \mathrm{l}$ reactions were set up with $100 \mathrm{ng}$ of RNA, $0.4 \mu \mathrm{M}$ primer, $0.2 \mu \mathrm{M}$ dual labeled probe, $0.5 \mu \mathrm{l}$ of QuantiTect ${ }^{\mathrm{mi}}$ Reverse Transcriptase Mix and QuantiTect ${ }^{\mathrm{mm}}$ Probe RT-PCR Master Mix. Real time PCR was performed using a Mx4000 Multiplex Quantitative PCR System (Stratagene, La Jolla, CA) with each sample assayed in triplicate. Three mRNA species were quantified, including CTGF and PAI-1 and the reference gene, GAPDH. Standard curves for all three genes were generated using serial dilution of RNA isolated from tissue of control mice. The relative mRNA amounts for each of the genes in the individual RNA samples were calculated from the standard curves. The following primers and Taqman probes were used: CTGF: Forward Primer: 5'-aagggcctcttctgcgattt-3'; Reverse Primer: 5'-tttggaaggactcaccgctg-3'; Probe: 5'-/56-FAM/ cctgtgtcttcggtgggtcggtgtac/3BHQ_1/-3'. PAI-1: Forward Primer: 5'-tgcatcgcctgccattg-3'; Reverse Primer: 5'-ggaccttgagataggacagtgctt-3'; Probe: 5'-/56-FAM/tggagggtgccatgggcca/3BHQ_1/-3'. GAPDH: Forward Primer: 5'gtcgtggatctgacgtgcc-3'; Reverse Primer: 5'-gatgcctgcttcaccacctt-3'; Probe: 5'-/56-FAM/cctggagaaacctgccaagtatgatgacat/3BHQ_1/-3'

\section{Statistical analysis}

One-way analysis of variance (ANOVA) tests and t-tests were performed using InStat (GraphPad Software, Inc., version 3.1a). Two-way repeated measures ANOVA tests and survival analyses were carried out using JMP (SAS Institute Inc., version 8).

\section{Competing interests}

MR has received consulting and speaker fees from Genzyme Corporation and from Eli Lilly \& Co. within the past five years.

\footnotetext{
Authors' contributions

VG and RG carried out the bulk of the in vitro and in vivo studies. AG carried out the 3D culture studies. WX carried out the immunostaining studies. WB-P assisted with the in vivo studies, particularly bioluminescence assays, and carried out TRAP staining. YK provided all of the metastatic cell lines and invaluable advice in design and analysis of the in vivo experiments. SL and JM provided 1D11 and guidance for its use in vitro and in vivo. JMY provided LY2109761 and guidance for its use in vitro and in vivo. SB and GRM carried out the Faxitron and morphometric analyses carried out the immunoassays. MT participated in the sequence alignment. ES participated in the design of the study and performed the statistical analysis. MR conceived of the study, and
}

participated in its design and coordination and helped to draft the manuscript. All authors read and approved the final manuscript.

\section{Acknowledgements}

We would like to thank Dr. Joan Massagué for providing us with the lung-tropic subclones MDA-MB-231 4175TR and MDA-MB-231 4173 used in this study. This work was supported by Public Health Service Awards CA-120623 to MR from the National Cancer Institute, as well as by Cancer Center Support Grant CA-72720 from the National Cancer Institute.

\section{Author Details}

1Division of Medical Oncology, Department of Internal Medicine, UMDNJRobert Wood Johnson Medical School and The Cancer Institute of New Jersey, New Brunswick, NJ, USA, 2Department of Molecular Biology, Princeton University, Princeton, NJ, USA, ${ }^{3}$ Genzyme Corporation, Framingham, MA, USA 4Lilly Research Laboratories, Indianapolis, IN, USA and 5Dept. of Cancer Biology, Vanderbilt Center for Bone Biology, Vanderbilt University School of Medicine, Nashville, TN, USA

Received: 7 February 2010 Accepted: 26 May 2010

Published: 26 May 2010

\section{References}

1. Strange R, Li F, Saurer S, Burkhardt A, Friis RR: Apoptotic cell death and tissue remodelling during mouse mammary gland involution. Development 1992, 115:49-58.

2. Gorska AE, Joseph H, Derynck R, Moses HL, Serra R: Dominant-negative interference of the transforming growth factor beta type II receptor in mammary gland epithelium results in alveolar hyperplasia and differentiation in virgin mice. Cell Growth Differ 1998, 9:229-238.

3. Barcellos-Hoff MH, Akhurst RJ: Transforming growth factor-beta in breast cancer: too much, too late. Breast Cancer Res 2009, 11:202.

4. Roberts AB, Tian F, Byfield SD, Stuelten C, Ooshima A, Saika S, Flanders KC: Smad3 is key to TGF-beta-mediated epithelial-to-mesenchymal transition, fibrosis, tumor suppression and metastasis. Cytokine Growth Factor Rev 2006, 17:19-27.

5. Piek E, Moustakas A, Kurisaki A, Heldin CH, ten Dijke P: TGF-(beta) type I receptor/ALK-5 and Smad proteins mediate epithelial to mesenchymal transdifferentiation in NMuMG breast epithelial cells. J Cell Sci 1999, 112:4557-4568

6. Narayan S, Thangasamy T, Balusu R: Transforming growth factor -beta receptor signaling in cancer. Front Biosci 2005, 10:1135-1145.

7. Inman GJ, Nicolas FJ, Hill CS: Nucleocytoplasmic shuttling of Smads 2, 3, and 4 permits sensing of TGF-beta receptor activity. Mol Cell 2002, 10:283-294

8. Massague J, Gomis RR: The logic of TGFbeta signaling. FEBS Lett 2006, 580:2811-2820

9. Bharathy S, Xie W, Yingling JM, Reiss M: Cancer-associated transforming growth factor beta type II receptor gene mutant causes activation of bone morphogenic protein-Smads and invasive phenotype. Cancer Res 2008, 68:1656-1666.

10. Liu IM, Schilling SH, Knouse KA, Choy L, Derynck R, Wang XF: TGFbetastimulated Smad1/5 phosphorylation requires the ALK5 L45 loop and mediates the pro-migratory TGFbeta switch. EMBO J 2009, 28:88-98.

11. Daly AC, Randall RA, Hill CS: Transforming growth factor beta-induced Smad1/5 phosphorylation in epithelial cells is mediated by novel receptor complexes and is essential for anchorage-independent growth. Mol Cell Biol 2008, 28:6889-6902.

12. Nikolic-Vukosavljevic D, Todorovic-Rakovic N, Demajo M, Ivanovic V, Neskovic B, Markicevic M, Neskovic-Konstantinovic Z: Plasma TGF-beta1related survival of postmenopausal metastatic breast cancer patients. Clin Exp Metastasis 2004, 21:581-585.

13. Ivanovic V, Demajo M, Krtolica K, Krajnovic M, Konstantinovic M, Baltic V, Prtenjak G, Stojiljkovic B, Breberina M, Neskovic-Konstantinovic Z, et al: Elevated plasma TGF-beta1 levels correlate with decreased survival of metastatic breast cancer patients. Clin Chim Acta 2006, 371:191-193.

14. Grau AM, Wen W, Ramroopsingh DS, Gao YT, Zi J, Cai Q, Shu XO, Zheng W: Circulating transforming growth factor-beta- 1 and breast cancer prognosis: results from the Shanghai Breast Cancer Study. Breast Cancer Res Treat 2007. 
15. O'Brien PJ, Ramanathan R, Yingling JM, Baselga J, Rothenberg ML, Carducci M, Daly T, Adcock D, Lahn M: Analysis and variability of TGFbeta measurements in cancer patients with skeletal metastases. Biologics 2008, 2:563-569.

16. Dalal BI, Keown PA, Greenberg AH: Immunocytochemical localization of secreted transforming growth factor-beta 1 to the advancing edges of primary tumors and to lymph node metastases of human mammary carcinoma. Am J Pathol 1993, 143:381-389.

17. MacCallum J, Bartlett JM, Thompson AM, Keen JC, Dixon JM, Miller WR Expression of transforming growth factor beta mRNA isoforms in human breast cancer [see comments]. Br J Cancer 1994, 69:1006-1009.

18. McCune BK, Mullin BR, Flanders KC, Jaffurs WJ, Mullen LT, Sporn MB: Localization of transforming growth factor-beta isotypes in lesions of the human breast [see comments]. Hum Pathol 1992, 23:13-20.

19. Walker RA, Dearing SJ: Transforming growth factor beta 1 in ductal carcinoma in situ and invasive carcinomas of the breast. Eur J Cancer 1992, 28:641-644.

20. Gorsch SM, Memoli VA, Stukel TA, Gold LI, Arrick BA: Immunohistochemical staining for transforming growth factor beta 1 associates with disease progression in human breast cancer. Cancer Res 1992, 52:6949-6952.

21. Tan AR, Alexe G, Reiss M: Transforming growth factor-beta signaling: emerging stem cell target in metastatic breast cancer? Breast Cancer Res Treat 2009, 115:453-495.

22. McEarchern JA, Kobie JJ, Mack V, Wu RS, Meade-Tollin L, Arteaga CL, Dumont N, Besselsen D, Seftor E, Hendrix MJ, et al: Invasion and metastasis of a mammary tumor involves TGF-beta signaling. Int $J$ Cancer 2001, 91:76-82.

23. Yin JJ, Selander K, Chirgwin JM, Dallas M, Grubbs BG, Wieser R, Massague J, Mundy GR, Guise TA: TGF-beta signaling blockade inhibits PTHrP secretion by breast cancer cells and bone metastases development. $J$ Clin Invest 1999, 103:197-206.

24. Tang B, Vu M, Booker T, Santner SJ, Miller FR, Anver MR, Wakefield LM: TGF\{beta\} switches from tumor suppressor to prometastatic factor in a model of breast cancer progression. J Clin Invest 2003, 112:1116-1124.

25. Kang Y, He W, Tulley S, Gupta GP, Serganova I, Chen CR, Manova-Todorova K, Blasberg R, Gerald WL, Massague J: Breast cancer bone metastasis mediated by the Smad tumor suppressor pathway. Proc Natl Acad Sci USA 2005, 102:13909-13914.

26. Deckers M, van Dinther M, Buijs J, Que I, Lowik C, Pluijm G van der, ten Dijke P: The tumor suppressor Smad4 is required for transforming growth factor beta-induced epithelial to mesenchymal transition and bone metastasis of breast cancer cells. Cancer Res 2006, 66:2202-2209.

27. Korpal M, Yan J, Lu X, Xu S, Lerit DA, Kang Y: Imaging transforming growth factor-beta signaling dynamics and therapeutic response in breast cancer bone metastasis. Nat Med 2009, 15:960-966

28. Kakonen SM, Selander KS, Chirgwin JM, Yin JJ, Burns S, Rankin WA, Grubbs BG, Dallas M, Cui Y, Guise TA: Transforming growth factor-beta stimulates parathyroid hormone-related protein and osteolytic metastases via Smad and mitogen-activated protein kinase signaling pathways. J Biol Chem 2002, 277:24571-24578.

29. Tian F, DaCosta Byfield S, Parks WT, Yoo S, Felici A, Tang B, Piek E, Wakefield $L M$, Roberts $A B$ : Reduction in Smad2/3 signaling enhances tumorigenesis but suppresses metastasis of breast cancer cell lines. Cancer Res 2003, 63:8284-8292.

30. Reiss M: Transforming Growth Factor- $\beta$ in metastasis: In vitro and in vivo mechanisms. In Transforming Growth Factor-beta in Cancer Therapy Volume II. Edited by: Jakowlew SB. Totowa, NY: The Humana Press, Inc; 2008:609-634

31. Dumont N, Arteaga CL: Targeting the TGF beta signaling network in human neoplasia. Cancer Cell 2003, 3:531-536.

32. Saunier EF, Akhurst RJ: TGF beta inhibition for cancer therapy. Curr Cancer Drug Targets 2006, 6:565-578.

33. Yingling JM, Blanchard KL, Sawyer JS: Development of TGF-beta signalling inhibitors for cancer therapy. Nat Rev Drug Discov 2004, 3:1011-1022.

34. Russo $L M$, Brown $D$, Lin HY: The soluble transforming growth factorbeta receptor: advantages and applications. Int J Biochem Cell Biol 2009, 41:472-476

35. Dasch JR, Pace DR, Waegell W, Inenaga D, Ellingsworth L: Monoclonal antibodies recognizing transforming growth factor-beta. Bioactivity neutralization and transforming growth factor beta 2 affinity purification. J Immunol 1989, 142:1536-1541.

36. Singh J, Chuaqui CE, Boriack-Sjodin PA, Lee WC, Pontz T, Corbley MJ, Cheung HK, Arduini RM, Mead JN, Newman MN, et al.: Successful shapebased virtual screening: the discovery of a potent inhibitor of the type I TGFbeta receptor kinase (TbetaRI). Bioorg Med Chem Lett 2003, $13: 4355-4359$

37. DaCosta Byfield S, Major C, Laping NJ, Roberts AB: SB-505124 Is a Selective Inhibitor of Transforming Growth Factor-\{beta\} Type I Receptors ALK4, ALK5, and ALK7. Mol Pharmacol 2004, 65:744-752.

38. Hjelmeland MD, Hjelmeland AB, Sathornsumetee $S$, Reese ED, Herbstreith MH, Laping NJ, Friedman HS, Bigner DD, Wang XF, Rich JN: SB-431542, a small molecule transforming growth factor-beta-receptor antagonist inhibits human glioma cell line proliferation and motility. Mol Cancer Ther 2004, 3:737-745.

39. Ge R, Rajeev V, Subramanian G, Reiss KA, Liu D, Higgins L, Joly A, Dugar S, Chakravarty J, Henson M, et al:: Selective inhibitors of type I receptor kinase block cellular transforming growth factor-beta signaling. Biochem Pharmacol 2004, 68:41-50

40. Li HY, McMillen WT, Heap CR, McCann DJ, Yan L, Campbell RM, Mundla SR, King $\mathrm{CH}$, Dierks EA, Anderson BD, et al: Optimization of a dihydropyrrolopyrazole series of transforming growth factor-beta type I receptor kinase domain inhibitors: discovery of an orally bioavailable transforming growth factor-beta receptor type I inhibitor as antitumor agent. J Med Chem 2008, 51:2302-2306.

41. Kareddula A, Zachariah E, Notterman D, Reiss M: Transforming Growth Factor- $\beta$ Signaling Strength Determines Target Gene Expression Profile in Human Keratinocytes. J Epithel Biol Pharmacol 2008, 1:40-94.

42. Kang Y, Siegel PM, Shu W, Drobnjak M, Kakonen SM, Cordon-Cardo C, Guise TA, Massague J: A multigenic program mediating breast cancer metastasis to bone. Cancer Cell 2003, 3:537-549.

43. Minn AJ, Gupta GP, Siegel PM, Bos PD, Shu W, Giri DD, Viale A, Olshen AB, Gerald WL, Massague J: Genes that mediate breast cancer metastasis to lung. Nature 2005, 436:518-524

44. Kang Y: Breast cancer bone metastasis: molecular basis of tissue tropism. J Musculoskelet Neuronal Interact 2004, 4:379-380.

45. Kang Y, Chen CR, Massague J: A self-enabling TGFbeta response coupled to stress signaling: Smad engages stress response factor ATF3 for Id1 repression in epithelial cells. Mol Cell 2003, 11:915-926.

46. Kenny P, Lee G, Myers C, Neve R, Semeiks J, Spellman P, Lorenz K, Lee E, Barcellos-Hoff M, Petersen O, et al: The morphologies of breast cancer cell lines in three-dimensional assays correlate with their profiles of gene expression. Molecular Oncology 2007, 1:84-96.

47. Muraoka RS, Dumont N, Ritter CA, Dugger TC, Brantley DM, Chen J, Easterly E, Roebuck LR, Ryan S, Gotwals PJ, et al:: Blockade of TGF-beta inhibits mammary tumor cell viability, migration, and metastases. Clin Invest 2002, 109:1551-1559.

48. Ge R, Rajeev V, Ray P, Lattime E, Rittling S, Medicherla S, Protter A, Murphy A, Chakravarty J, Dugar S, et al.: Inhibition of growth and metastasis of mouse mammary carcinoma by selective inhibitor of transforming growth factor-beta type I receptor kinase in vivo. Clin Cancer Res 2006, 12:4315-4330

49. Arteaga CL, Hurd SD, Winnier AR, Johnson MD, Fendly BM, Forbes JT: Antitransforming growth factor (TGF)-beta antibodies inhibit breast cancer cell tumorigenicity and increase mouse spleen natural killer cell activity. Implications for a possible role of tumor cell/host TGF-beta interactions in human breast cancer progression. J Clin Invest 1993, 92:2569-2576

50. Ehata S, Hanyu A, Fujime M, Katsuno Y, Fukunaga E, Goto K, Ishikawa Y Nomura K, Yokoo H, Shimizu T, et al.: Ki26894, a novel transforming growth factor beta type I receptor kinase inhibitor, inhibits in vitro invasion and in vivo bone metastasis of a human breast cancer cell line. Cancer Sci 2007, 98:127-133.

51. Pinkas J, Teicher BA: TGF-beta in cancer and as a therapeutic target. Biochem Pharmacol 2006, 72:523-529.

52. Nam JS, Suchar AM, Kang MJ, Stuelten CH, Tang B, Michalowska AM, Fisher LW, Fedarko NS, Jain A, Pinkas J, et al:: Bone sialoprotein mediates the tumor cell-targeted prometastatic activity of transforming growth factor beta in a mouse model of breast cancer. Cancer Res 2006, 66:6327-6335

53. Nam JS, Terabe M, Kang MJ, Chae H, Voong N, Yang YA, Laurence A, Michalowska A, Mamura M, Lonning S, et al.: Transforming growth factor 
beta subverts the immune system into directly promoting tumor growth through interleukin-17. Cancer Res 2008, 68:3915-3923.

54. Nam JS, Terabe M, Mamura M, Kang MJ, Chae H, Stuelten C, Kohn E, Tang $B$, Sabzevari H, Anver MR, et al:: An anti-transforming growth factor beta antibody suppresses metastasis via cooperative effects on multiple cell compartments. Cancer Res 2008, 68:3835-3843.

55. Miettinen PJ, Ebner R, Lopez AR, Derynck R: TGF-beta induced transdifferentiation of mammary epithelial cells to mesenchymal cells: involvement of type I receptors. Journal of Cell Biology 1994, 127:2021-2036.

56. Wrighton $\mathrm{KH}$, Lin X, Yu PB, Feng XH: Transforming Growth Factor \{beta\} Can Stimulate Smad1 Phosphorylation Independently of Bone Morphogenic Protein Receptors. J Biol Chem 2009, 284:9755-9763.

57. Futakuchi M, Nannuru KC, Varney ML, Sadanandam A, Nakao K, Asai K, Shirai T, Sato SY, Singh RK: Transforming growth factor-beta signaling at the tumor-bone interface promotes mammary tumor growth and osteoclast activation. Cancer Sci 2009, 100:71-81.

58. Mohammad KS, Chen CG, Balooch G, Stebbins E, McKenna CR, Davis H, Niewolna M, Peng XH, Nguyen DH, lonova-Martin SS, et al.: Pharmacologic inhibition of the tgf-Beta type I receptor kinase has anabolic and anti-catabolic effects on bone. PLOS ONE 2009, 4:e5275.

59. Carano R, Li Y, Bao M, Li J, Berry L, Ross J, Kowalski J, French D, Dugger D, Schwall $R$, et al: Effect of anti-TGF-beta antibodies in syngeneic mouse models of metastasis. J Musculoskelet Neuronal Interact 2004, 4:377-378

60. Debnath J, Muthuswamy SK, Brugge JS: Morphogenesis and oncogenesis of MCF-10A mammary epithelial acini grown in threedimensional basement membrane cultures. Methods 2003, 30:256-268.

61. Yu L, Border WA, Anderson I, McCourt M, Huang Y, Noble NA: Combining TGF-beta inhibition and angiotensin II blockade results in enhanced antifibrotic effect. Kidney Int 2004, 66:1774-1784.

62. Li HY, Wang Y, Heap CR, King CH, Mundla SR, Voss M, Clawson DK, Yan L, Campbell RM, Anderson BD, et al:: Dihydropyrrolopyrazole transforming growth factor-beta type I receptor kinase domain inhibitors: a novel benzimidazole series with selectivity versus transforming growth factor-beta type II receptor kinase and mixed lineage kinase-7. J Med Chem 2006, 49:2138-2142.

doi: $10.1186 / 1476-4598-9-122$

Cite this article as: Ganapathy et al., Targeting the Transforming Growth Factor-? pathway inhibits human basal-like breast cancer metastasis Molecular Cancer 2010, 9:122

Submit your next manuscript to BioMed Centra and take full advantage of:

- Convenient online submission

- Thorough peer review

- No space constraints or color figure charges

- Immediate publication on acceptance

- Inclusion in PubMed, CAS, Scopus and Google Scholar

- Research which is freely available for redistribution

Submit your manuscript at www.biomedcentral.com/submit
C Biomed Central 